\title{
Pelaksanaan Lelang Terhadap Obyek Yang Dibebani Hak Tanggungan Dalam Rangka Mewujudkan Keadilan Para Pihak
}

\author{
Pandu Dwi Nugroho, Siti Malikhatun Badriyah \\ Program Kajian Hukum Ekonomi dan Bisnis Universitas Diponegoro \\ pandudwinugroho@gmail.com
}

\begin{abstract}
This research is about the implementation of auctions the mortgage realize the justice of the parties. The problem of research is whether the collateral that has been installed by KPKNL as well as how the auction for the object of mortgage rights can realize the justice of the parties. This study accomply normative approach. Legal materials obtained from legislation, legal theory, and the opinions of prominent scholars were then analyzed juridically. The results showed that the KPKNL in accordance with the Minister of Finance Regulation No. 102 / PMK.01/2008 concerning Organizations and Work Procedures of Vertical Agencies of the Directorate General of State Wealth Article 29 paragraph (1). Law Number 4 of 1996 Article 10 paragraph (1) stipulates that the granting of mortgages is preceded by a promise about collateral for repayment of certain debt, which is an inseparable part of the agreement of the related debt. The mortgage is under the authority of recipients of mortgage rights. This is to provide legal protection and certainty to creditors if the debtor fails to make a promise. If there is a breach of contract, the object pledged as collateral will be sold to pay off the guaranteed debtor's debt.
\end{abstract}

Keywords : Auctions, Deposit Rights, Justice of the Parties

\begin{abstract}
Abstrak
Penelitian ini tentang pelaksanaan lelang terhadap obyek lelang yang dibebani hak tanggungan guna mewujudkan keadilan para pihak. Permasalahan penelitian adalah apakah agunan yang telah dipasang Akta Pembebanan Hak Tanggungan dapat langsung dilelang melalui Kantor Pelayanan Kekayaan Negara dan Lelang serta bagaimana pelaksanaan lelang terhadap obyek hak tanggungan yang dapat mewujudkan keadilan para pihak. Penelitian ini menggunakan pendekatan yuridis normatif. Bahan hukum diperoleh dari peraturan perundang-undangan, teori hukum, dan pendapat para sarjana terkemuka kemudian dianalisis secara yuridis. Hasil penelitian menunjukkan bahwa pelaksanaan lelang dilakukan oleh Kantor Pelayanan Kekayaan Negara dan Lelang (KPKNL) sesuai dengan Peraturan Menteri Keuangan No. 102 /PMK.01/2008 tentang Organisasi Dan Tata Kerja Instansi Vertikal Direktorat Jendral Kekayaan Negara Pasal 29 ayat (1). Undang Undang Nomor 4 Tahun 1996 Pasal 10 ayat (1) menentukan bahwa Pemberian hak tanggungan didahului dengan janji untuk memberikan hak tanggungan sebagai jaminan pelunasan hutang tertentu, yang merupakan bagian tak terpisahkan dari perjanjian utang piutang yang bersangkutan. Objek yang
\end{abstract}


dibebankan atas hak tanggungan berada di bawah kekuasaan penerima hak tanggungan. Hal ini bertujuan untuk memberikan perlindungan dan kepastian hukum kepada kreditur apabila debitur cidera janji. Jika terjadi cidera janji, benda yang dijaminkan dengan hak tanggungan akan dijual untuk melunasi utang debitur yang dijamin tersebut.

\section{Kata kunci : Lelang, Hak Tanggungan, Keadilan Para Pihak}

\section{Pendahuluan}

Manusia dalam menjalani

kehidupan di muka bumi ini tentunya tidak terlepas dari kepentingan. Dalam rangka pemenuhan dan melindungi kepentingan tersebut, manusia melakukan kerjasama dengan manusia lain untuk memudahkan mewujudkannya. Setiap hubungan hukum dalam masyarakat didasarkan pada asasasas hukum (Badriyah, 2016 : 90).

J.J.H. Bruggink mengemukakan bahwa asas hukum adalah sejenis meta kaidah berkenaan dengan kaidah-kaidah perilaku. (Bruggink, 1999 : 132). Mengingat akan banyaknya kepentingan tadi maka tidak mustahil akan terjadi konflik atau bentrokan antara sesama manusia karena kepentingannya saling bertentangan. Selama tidak ada kepentingan manusia "conflict of human interest" atau selama kepentingan manusia tidak dilanggar, maka tidak akan ada yang mempersoalkan siapa yang benar dan siapa yang salah (Mertokusumo, 1996 : 3).

Perlindungan hukum seharusnya diperlukan untuk memerangi persoalan-persoalan yang akan terjadi pada setiap manusia itu sendiri.Undang-Undang Dasar 1945 Pasal 33 ayat (3) menjelaskan "Bumi dan air dan kekayaan yang terkandung didalamnya dikuasai oleh negara dan dipergunakan untuk sebesar-besarnya kemakmuran rakyat". Dengan adanya penjelasan tersebut telah jelas bahwa hakekat dari isi bumi adalah untuk kepentingan dan kemakmuran rakyat. Negara hanya mengatur bagaimana hak tersebut dilaksanakan oleh rakyat dan membatasinya dengan berbagai produk peraturan yang secara adil melindungi hak yang dimiliki oleh setiap individu untuk kepentingan umum agar tercapainya suatu masyarakat yang adil dan makmur. Hukum menguasai dan mencampuri 
setiap urusan hidup manusia yang kemudian muncul korelasi antara hukum dengan manusia sebagai subjek hukum adalah dengan adanya hak dan kewajiban yang timbul dari setiap perilaku manusia, manusia merupakan subyek pendukung hak dan kewajiban tersebut, segala benda yang mengelilingi kita merupakan obyek hak, sehingga timbulah ikatan hukum yang jumlahnya tak terhingga, yang menghubungkan antara manusia yang satu dengan manusia yang lain. Semua ikatan hukum tersebut merupakan hubungan yang kesemuanya diatur oleh hukum, jadi semuanya adalah hubungan hukum (rechtsbetrekkingen), sehingga kita berpikir bahwa hukum tak terbatas melainkan terdapat dimana-mana. (Apeldorn, $2001: 6$ ).

Salah satu obyek hak yang terdapat di dalam lingkungan masyarakat adalah tanah, dan setiap individu berhak untuk memiliki obyek hak (tanah) tersebut, sehingga apabila kita berbicara mengenai adanya obyek hak, lalu bagaimanakah cara individu tersebut memperoleh obyek hak (tanah) tersebut Adapun hak-hak atas tanah dapat diperoleh dengan cara jual beli, Menurut Harun Al-Rashid, pada hakekatnya jual beli merupakan salah satu cara pengalihan hak atas tanah kepada pihak pembeli tanah dari pihak penjual tanah. (Al-Rashid, 1997 : 50). Proses Penjualan tanah tersebut dibedakan menjadi dua cara yaitu penjualan secara umum dan penjualan khusus secara lelang yang dilakukan oleh Kantor Pelayanan Kekayaan Negara dan Lelang (KPKNL).

Istilah lelang sudah akrab terdengar dalam kehidupan seharihari, namun tidak banyak orang yang memahami bagaimana ruang lingkup dan tata cara lelang. Dalam hal ini semua pelaksanaan lelang, mulai dari persiapan samapai dengan purna lelang, dilaksanakan sesuai dengan ketentuan Vendu Reglement (Peraturan Penjualan di Muka Umum Indonesia) yang diatus dalam S.1940-56 jo S. 1941-3 dan Peraturan Menteri Keuangan (PMK) Nomor 106/PMK.06/2013 tentang Petunjuk Pelaksanaan Lelang yang merupakan penganti PMK Nomor 
93/PMK.06/2010 tentang Peraturan yang sama.

Lelang adalah barang yang terbuka untuk umum dengan penawaran secara tertulis dan/atau lisan yang semakin mengikat atau menurun untuk mencapai harga tertinggi yang didahului dengan pengumaman lelang (Ngadijarmo, Laksito, \& Listani, 2006 : 1). Pengumuman lelang adalah pemberitahuan kepada masyarakat tentang akan adanya lelang dengan maksud untuk menghimpun peminat lelang dan pemberitahuan kepada pihak berkepentingan. (Ngadijarmo, Laksito, Listani, 2006 : 3)

Tujuan daripada lelang hak atas tanah adalah agar pembeli lelang dapat secara sah menguasai dan menggunakan tanah. Sebagaimana diketahui bahwa tanah merupakan benda yang memiliki nilai ekonomis tinggi. Peraturan yang ada terkait dengan lelang tersebut terkadang tidak mampu dalam menampung kasus-kasus yang terjadi di masyarakat. Peralihan hak dengan pelelangan hanya dapat didaftar jika dibuktikan dengan kutipan risalah lelang yang dibuat oleh Pejabat
Lelang baik dalam lelang eksekusi dan lelang sukarela (Harsono, 2008 : 516). Peraturan Menteri Keuangan Nomor 106/PMK.06/2013 tentang Perubahan Atas Peraturan Menteri Keuangan Nomor 93/PMK/06/2010 tentang Petunjuk Pelaksanaan Lelang, yang menyatakan bahwa "Lelang adalah penjualan barang yang terbuka untuk umum dengan penawaran harga secara tertulis dan atau lisan yang semakin meningkat atau menurun untuk mencapai harga tertinggi yang didahului dengan pengumuman lelang." Undangundang Nomor 19 Tahun 2000 tentang Perubahan atas UndangUndang Nomor 19 Tahun 1997 tentang Penagihan Pajak dengan Surat Paksa, Pasal 1 sub 17 menyatakan "Lelang adalah penjualan barang di muka umum dengan cara penawaran harga secara lisan dan atau tertulis melalui usaha pengumpulan calon pembeli atau peminat." Salah satu upaya untuk mewujudkan kesejahteraan bagi masyarakat adalah adanya pembangunan nasional berupa pembangunan ekonomi. 


\begin{abstract}
Secara normatif, sebenarnya tidak ada peraturan perundangundangan yang mengatur tentang asas lelang. Namun, apabila dicermati dari klausula-klausula dalam peraturan perundangundangan di bidang lelang dapat ditemukan adanya asas lelang, yaitu:
\end{abstract}

\section{a) Asas Transparansi}

Asas ini mengandung makna bahwa cara penjualan umum melalui lelang dilakukan di muka umum. Lelangnya pun harus diumumkan terlebih dahulu, agar masyarakat mengetahui akan adanya lelang dan barang lelangnya cepat terjual. Lelang harus dikontrol ini terbukti dengan adanya sistem lelang yang sudah diatur dalam peraturan perundangundangan untuk memberikan perlindungan/kepastian kepada masyarakat/pembeli mengenai objek lelang tersebut. Oleh karena itu, setiap pelaksanaan lelang harus didahului dengan pengumuman lelang. Asas ini juga untuk mencegah terjadinya praktek persaingan usaha tidak sehat, dan tidak memberikan kesempatan adanya praktek korupsi, kolusi dan nepotisme (KKN).

\section{b) Asas Akuntabilitas}

Maksud akuntabilitas adalah lelang dalam pelaksanaannya dapat dipertanggungjawabkan. Hal ini dibuktikan dengan adanya akta yang bersifat. Salah satu objek lelang dalam pelelangan yaitu hak tanggungan, Undang-undang Hak Tanggungan dibentuk sebagai pelaksanaan dari Pasal 51 UUPA yang menggantikan berlakunya ketentuan-ketentuan mengenai hypotheek yang diatur dalam Kitab Undang-undang Hukum Perdata dan Creditverband yang diatur dalam Staatsblad $1908 \quad$ No. 542 sebagaimana telah diubah dengan Staatsblad 1937 No. 190. Hak Tanggungan adalah merupakan salah satu jenis jaminan kebendaan yang meskipun tidak dinyatakan dengan tegas, adalah jaminan yang lahir dari suatu perjanjian otentik yaitu Akta Risalah Lelang yang dibuat oleh Pejabat Lelang dan sistem pelaksanaan lelang sudah diatur oleh Undang-Undang.

\section{c) Asas Efisiensi}

Menjamin pelaksanaan lelang dilakukan dengan cepat dan dengan biaya yang relatif murah karena lelang dilakukan dalam tempat dan 
waktu yang telah ditentukan dan pembeli disahkan saat itu juga. Pelaksanaan lelang tidak membutuhkan waktu yang lama, tidak perlu mencari-cari pembeli dan tidak perlu bernegosiasi seperti transaksi jual beli pada umumnya. Tidak hanya itu saja, objek lelang pun sebelumnya telah diteliti baik fisik maupun aspek juridisnya oleh pejabat lelang dan transaksi lelang dilakukan pada satu waktu dan pada satu tempat yang telah ditentukan. Penjualannya pun tidak diperkenankan melalui perantara dan pembayarannya bersifat tunai.

\section{d) Asas Certainty (kepastian)}

Kepastian lelang sudah diatur sebagaimana dalam Peraturan Menteri Keuangan Pelaksanaan Lelang, yaitu Lelang dipimpin oleh Pejabat Lelang yang diselenggarakan oleh Kantor Lelang Negara. Tempat, tanggal, waktu dan objek lelang telah ditetapkan sebelumnya dan diumumkan kepada masyarakat. Pelaksanaan lelang tidak mudah untuk ditunda atau dibatalkan kecuali melalui putusan/penetapan pengadilan.

e) Asas Keadilan
Mengandung pengertian bahwa dalam proses pelaksanaan lelang harus dapat memenuhi rasa keadilan secara proporsional bagi setiap pihak yang berkepentingan. Asas ini untuk mencegah terjadinya keberpihakan pejabat lelang kepada peserta lelang tertentu atau berpihak hanya kepada kepentingan penjual. Khusus pada pelaksanaan lelang eksekusi, penjual lelang tidak dapat menentukan harga limit secara sewenang-wenang yang berakibat merugikan pihak tereksekusi.

Gunawan Setiardjo mendefinisikan keadilan sebagai berikut: Keadilan itu adalah (diambil dalam arti subjektif) suatu kebiasaan baik jiwa yang mendorong manusia dengan kemauan tetap dan terus menerus untuk memberikan kepada setiap orang apa yang yang menjadi haknya". Keadilan itu adalah konkret dengan melihat pernyataan dalam Pembukaan UUD Negara Republik Indonesia 1945, khususnya alinea ke4. (Rahardjo, 2004 : 56).

Berdasarkan asas-asas lelang yang diuraikan di atas, menimbulkan beberapa kebaikan lelang. Menurut Peraturan Menteri Keuangan 
Republik Indonesia Nomor 106/PMK.06/2013 Perubahan Atas Peraturan Menteri Keuangan 93/PMK.06/2010 tentang Petunjuk Pelaksanaan, kebaikan lelang antara lain adalah aman, cepat, dan mewujudkan harga yang wajar, selain itu kebaikan lelang yaitu dapat memberikan kepastian hukum bagi pelaksanaan lelang.

Jika dilihat dari ketentuan yang diatur dalam Pasal 10, Pasal 11, dan Pasal 12 UUHT dapat diketahui bahwa pada dasarnya pemberian Hak Tanggungan hanya dapat dimungkinkan jika dibuat dalam bentuk perjanjian. Dalam pemenuhan pemberian hak tanggungan tentunya harus memenuhi syarat sahnya perjanjian sebagaimana diatur dalam Pasal 1320 Kitab Undang-undang Hukum Perdata. Untuk sahnya perjanjian-perjanjian, diperlukan 4 (empat) syarat yaitu:

1) Sepakat mereka yang mengikatkan dirinya ;

2) Kecakapan untuk membuat suatu perjanjian ;

3) Suatu hal tertentu ;

4) Suatu sebab yang halal ;
Landasan Hukum Eksekusi Hak Tanggungan diatur dalam Pasal 20 UUHT, dimana dalam Pasal tersebut dapat diketahui bahwa pada dasarnya eksekusi atau penjualan hak atas tanah yang dibebani dengan Hak Tanggungan dapat dilaksanakan melalui 2 cara :

1) Lelang berdasarkan ketentuan Pasal 6 UUHT Apabila debitor cidera janji, pemegang hak tanggungan pertama mempunyai hak untuk menjual obyek hak tanggungan atas kekuasaan sendiri melalui pelelangan umum serta mengambil pelunasan piutangnya dari hasil penjualan tersebut.

2) Lelang berdasarkan Pasal 20 Ayat (1) huruf b jo. Pasal 14 Ayat (2). Rumusan Pasal 14 ayat (2) UUHT secara jelas menyatakan bahwa sertipikat Hak Tanggungan mempunyai kekuatan eksekutorial sebagaimana halnya suatu putusan pengadilan yang telah berkekuatan hukum tetap.

Melalui penjualan secara lelang, seorang pembeli akan terjamin kepastian hukumnya atas 
kepemilikan obyek lelang (tanah) tersebut, karena dari setiap pelaksanaan lelang akan diterbitkan risalah lelang yang merupakan akta otentik dari pembelian suatu barang melalui proses penjualan secara lelang, sehingga dengan alat bukti risalah lelang tersebut hak kepemilkan atas obyek lelang (tanah) akan jatuh kepada pihak pemenang lelang, meskipun belum secara sempurna mendapat hak atas tanah tersebut, karena hak atas tanah tersebut harus didaftarkan, guna memperoleh legitimasi yang sempurna akan hak atas tanah tersebut kepada Kantor Pertanahan setempat.

\section{Tujuan Penelitian}

Tujuan penelitian ini adalah :

1) Untuk mengetahui dan menganalisis obyek lelang dengan agunan yang telah dipasang Akta Pembebanan Hak Tanggungan dapat langsung dilelang melalui Kantor Pelayanan Kekayaan Negara dan Lelang.

2) Untuk mengetahui dan menganalisis pelaksanaan lelang terhadap obyek hak tanggungan dapat mewujudkan keadilan para pihak.

\section{Metode Penelitian}

\section{a) Pendekatan masalah}

Penelitian ini menggunakan pendekatan yuridis normatif. Pendekatan yuridis normatif adalah pendekatan yang dilakukan berdasarkan bahan hukum dengan cara menelaah teori-teori, konsepkonsep, asas-asas hukum serta peraturan perundang-undangan yang berhubungan dengan penelitian ini. Pendekatan ini dikenal pula dengan pendekatan kepustakaan, yakni dengan mempelajari bukubuku,peraturan perundang-undangan dan dokumen lain yang berhubungan dengan penelitian ini. Secara khusus, penelitian ini akan meneliti tentang pelelangan hak tanggungan oleh KPKNL Semarang.

\section{b) Spesifikasi Penelitian}

Dalam penelitian ini, spesifikasi penelitian yang akan digunakan peneliti adalah deskriptif analitis, yakni suatu penelitian yang berusaha menggambarkan masalah hukum, sistem hukum dan mengkajinya atau 
menganalisisnya yang berkaitan Objek lelang Hak tanggungan Di Kota Semarang. Deskriptif analitis tersebut menggambarkan suatu peraturan perundang-undangan yang berlaku dikaitkan dengan teori-teori hukum dan praktik pelaksanaan hukum positif yang menyangkut objek masalah yang dihadapi. Dalam arti lain, prosedur atau cara memecahkan permasalahan dalam penelitian adalah dengan memaparkan keadaan objek yang diselidiki sebagaimana adanya, berdasarkan faktor-faktor aktual pada saat sekarang. Data deskriptif analitis yaitu data yang dinyatakan oleh responden secara tertulis atau lisan juga tingkah laku yang nyata, yang diteliti, dan dipelajari sebagai sesuatu yang utuh (Fajar, 2010 : 192).

c) Sumber dan Jenis Data

1) Bahan Hukum Primer

Yaitu norma atau kaidah dasar, peraturan perundang-undangan.

Dalam penelitian ini, bahan hukum primer yang digunakan adalah:

a) Undang-Undang Dasar Negara Republik Indonesia Tahun 1945 (UUD NRI Tahun 1945). b) Kitab Undang-Undang Hukum Perdata

c) Kitab Undang-Undang Hukum Acara Perdata

d) Undang-undang No.5 Tahun 1960 Tentang Pokok-Pokok Agraria.

e) Undang-Undang No.49/PRP Tahun 1960 Tentang Panitia Urusan Piutang Negara

f) UU No.4 Tahun 1996 Tentang Hak Tanggungan Atas Tanah Beserta Benda-Benda Yang Berkaitan Dengan Tanah

g) UU No.4 Tahun 1996 Tentang Hak Tanggungan

h) UU No.10 Tahun 1998 Tentang Perbankan

i) UU No.42 Tahun 1999 Tentang Jaminan Fidusia

j) UU No.37 Tahun 2004 Tentang Kepailitan dan Penundaan Kewajiban Membayar Utang

k) PMK No. 106/PMK.06/2013 Tentang Petunjuk Pelaksanaan Lelang

1) PMK No. 102 /PMK.01/2008 Tentang Organisasi Dan Tata Kerja Instansi Vertikal Direktorat Jenderal Kekayaan Negara 
2) Bahan Hukum Sekunder

Yaitu hasil karya ilmiah dari kalangan hukum, hasil-hasil penelitian, artikel koran dan internet serta bahan lain yang berkaitan dengan pokok bahasan.

3) Bahan Hukum Tersier

Yaitu bahan yang memberi penjelasan terhadap bahan hukum primer dan sekunder, yakni kamus hukum, kamus besar bahasa Indonesia dan sebagainya.

\section{d) Teknik Pengumpulan Data}

Mengingat penelitian ini memusatkan perhatian pada data sekunder maka pengumpulan data terutama ditempuh dengan melakukan penelitian kepustakaan dan studi dokumen. Teknik pengumpulan data dalam penelitian ini dilakukan dengan cara Studi kepustakaan. Studi kepustakaan yang dimaksud di sini adalah teknik pengumpulan data dengan mempelajari buku-buku, dokumen, peraturan perundang-undangan, laporan, arsip, literatur, dan hasil penelitian lainnya. Data yang diperoleh melalui literatur yang didapat berbagai buku dan majalah berkaitan dengan objek lelang hak tanggungan di Kota Semarang.

\section{1) Teknik Analisis Data}

Analisis data adalah proses mengatur urutan data, mengorganisasikannya ke dalam suatu pola, kategori, dan satuan uraian dasar (Fajar, 2010 : 157). Metode analisis yang digunakan dalam penelitian ini adalah metode analisis kualitatif karena merupakan analisis yang mendasarkan pada adanya hubungan semantis antar konsep (variabel) yang sedang diteliti. Tujuannya ialah peneliti mendapatkan makna hubungan konsepsional sehingga dapat digunakan untuk menjawab masalah yang dirumuskan dalam penelitian. Hubungan antarsemantis sangat penting karena dalam analisis kualitatif, peneliti tidak menggunakan angka-angka seperti pada analisis kuantitatif (Fajar, 2010 : 159). Pada prinsip pokok teknik analisis kualitatif ialah mengolah dan menganalisis data yang terkumpul menjadi data yang sistematis, teratur, terstruktur dan mempunyai makna.

\section{Pembahasan}

1) Pelaksanaan Obyek Lelang dengan Agunan yang Dibebani 
Akta Pembebanan Hak dan Lelang (KPKNL) merupakan Tanggungan

Hak Tanggungan merupakan pengikatan jaminan yang sering digunakan di dalam pelaksanaan pembiayaan, khususnya untuk menjamin jaminan yang berupa benda tidak bergerak yang diikat dengan perjanjian pengikatan berupa Surat Kuasa Membebankan Hak Tanggungan (SKMHT) dan Akta Pemberian Hak Tanggungan (APHT) yang didasarkan dari perjanjian pokok yang dibuat oleh nasabah dan bank selaku penerima jaminan. Pengaturan mengenai Hak Tanggungan diatur dalam Undang Undang No.4 Tahun 1996 Tentang Undang - Undang Hak Tanggungan (UUHT).

Pelaksanaan lelang dilakukan oleh Kantor Pelayanan Kekayaan Negara dan Lelang (KPKNL) diatur dalam Peraturan Menteri Keuangan No. 102 /PMK.01/2008 tentang Organisasi Dan Tata Kerja Instansi Vertikal Direktorat Jendral Kekayaan Negara Pasal 29 ayat (1), bahwa Kantor Pelayanan Kekayaan Negara instansi vertikal Dir ${ }^{1}$ ektorat Jenderal Kekayaan Negara (DJKN) yang berada di bawah dan bertanggung jawab langsung kepada Kepala Kantor Wilayah yang dipimpin oleh seorang Kepala.

Kata "instansi vertikal" dalam kalimat di atas, mempunyai maksud bahwa KPKNL pada dasarnya merupakan kantor operasional Direktorat Jenderal Kekayaan Negara (DJKN). Oleh karena KPKNL sebagai kantor operasional dari DJKN, maka KPKNL juga melaksanakan tugas-tugas dari DJKN yang ada di daerah.

Pengumuman lelang biasanya dilakukan di media surat kabar dan media lainnya, dalam hal ini KPKNL akan mengkaji suatu proses pelelangan sehingga menyelesaikan masalah sehingga menciptakan lelang yang adil dan terbuka yang menjadi kemudahan bagi masyarakat.

2) Pelaksanaan Lelang terhadap Objek Hak Tanggungan untuk 


\section{Mewujudkan Keadilan Para Pihak}

Perjanjian perikatan yang dilakukan oleh para pihak tersebut diatas apabila terjadi wanprestasi atau gagal bayar nantinya akan dilakukan eksekusi yang salah satunya adalah mekanisme lelang barang jaminan. Pelaksanaan lelang untuk memudahkan penyelesaian terjadi wanprestasi. Oleh karena itu, penelitian ini ingin mengkaji Lelang Barang Jaminan Hak Tanggungan.

Secara yuridis, hak tanggungan adalah hak jaminan atas tanah yang dibebankan pada hak milik, hak guna bangunan, hak guna usaha dan hak pakai, berikut atau tidak berikut benda - benda lain yang merupakan satu kesatuan dengan tanah itu, untuk pelunasan utang tertentu, yang memberikan kedudukan yang diutamakan kepada kreditur tertentu terhadap kreditur-kreditur lain dalam mengambil pelunasan piutangnya. Jelas dalam pengertian di atas disebutkan bahwa hak tanggungan merupakan hak jaminan atas tanah bukan tanah sebagai jaminan. Hak jaminan atas tanah merupakan jaminan yang menempatkan hak-hak atas tanah secara yuridis sebagai objeknya, bukan tanah secara fisiknya.

Hak tanggungan timbul karena adanya suatu perjanjian, sehingga ada kesepakatan antara kedua belah pihak dengan memberikan hak tanggungan. Rumusan Pasal 10 ayat (1) Undang-Undang Hak Tanggungan menyatakan bahwa "Pemberian hak tanggungan didahului dengan janji untuk memberikan hak tanggungan sebagai jaminan pelunasan hutang tertentu, yang dituangkan di dalam dan merupakan bagian tak terpisahkan dari perjanjian utang piutang yang bersangkutan atau perjanjian lainnya yang menimbulkan utang tersebut".

Salah satu ciri dari hak tanggungan adalah pelaksanaan yang pasti dari eksekusinya serta hak-hak istimewa yang terdapat di dalam hak tanggungan tersebut yang lebih ditujukan kepada penerima hak tanggungan. Keistimewaan tersebut terdapat dalam salah satu asas hak tanggungan yaitu memberikan kedudukan yang diutamakan (preferent) kepada krediturnya. Objek yang dibebankan atas hak 
anggungan berada di bawah kekuasaan penerima hak tanggungan. Hal ini bertujuan untuk memberikan perlindungan dan kepastian hukum kepada kreditur apabila debitur cidera janji. Jika terjadi cidera janji, benda yang dijaminkan dengan hak tanggungan akan dijual untuk melunasi utang debitur yang dijamin tersebut.

\section{Simpulan}

Hasil analisis dan pembahasan tentang pelaksanaan lelang terhadap obyek yang dibebani hak tanggungan dalam rangka mewujudkan keadilan para pihak, dapat disimpulkan sebagai berikut:

a) Pihak kreditur dalam hal ini pihak perbankan dapat menambah perputaran modal dari adanya uang pokok dari hasil pelelangan.

b) Pihak debitur berusaha untuk melunasi pnjaman serta adanya pencairan agunan.

\section{Saran}

Saran-saran yang dapat
disampikan terkait dengan
pelaksanaan lelang terhadap obyek
yang dibebani hak tanggungan dalam

rangka mewujudkan keadilan para pihak, diantaranya:

a) Bagi pihak debitur jika dalam proses lelang tersebut terdapat kelebihan atau sisa dari pejualan dapat dikembalikan kepada pihak debitur.

b) Bagi kantor lelang dengan adanya pelaksanaan lelang hak tanggungan karena kredit macet tersebut eksistensi KPKNL diakui dalam hal penyelesaian kredit macet melalui proses lelang

\section{Daftar Pustaka}

\section{Buku}

Siti Malikhatun Badriyah. 2016, Sistem Penemuan Hukum dalam Masyarakat Primastik, Jakarta: Sinar Grafika.

J.J.H. Bruggink. 1999, RechtsReflecties, diterjemahkan oleh Arief Sidharta dengan judul buku Refleksi Tentang Hukum, Bandung : Citra Aditya Bakti

Sudikno Mertokusumo. 1996, Mengenal Hukum, Edisi ke 4, Liberty : Yogyakarta

L.J. Van Apeldorn Mr. 2001, Pengantar Ilmu Hukum, Pradnya Paramita : Jakarta 
Harun Al-Rashid. 1997, Sekilas Jual Beli Tanah,Jakarta : Ghalia Indonesia

F.x. Ngadijarmo, Nunung Eko Laksito, Isti Indri Listani. 2006, Lelang Teori dan Praktek, Jakarta : Badan Pendidikan dan Pelatihan

Boedi Harsono. 2008, Hukum Agraria Indonesia Sejarah Pembentukan UndangUndang Pokok Agraria, Isi dan Pelaksanaannya, Jilid 1, Cet. XII, Jakarta : Djambatan

Hans Kelsen. 2008, Teori Umum Tentang Hukum dan Negara, Bandung: Nusa Media

Satjipto Rahardjo. 2010, Ilmu Hukum, Bandung: Citra Aditya Bakti

Lawrence M Friedman. 2009, Sistem hukum; Prespektif Ilmu Sosial (The Legal System; A Social Science Prespective), Bandung : Nusa Media

Philipus M. Hadjon. 1987, Perlindungan Hukum bagi Rakyat Indonesia: Sebuah Studi tentang PrinsipPrinsipnya, Penanganannya oleh Pengadilan dalam Lingkungan Peradilan Umum dan Pembentukan Peradilan Administrasi Negara, Surabaya : Bina Ilmu

Soerjono Soekanto. 1999, Penegakan Hukum, Bandung : Binacipta
Lili Rasjidi dan I. B. Wyasa Putra. 2003, Hukum Sebagai Suatu Sistem, Bandung: Remaja Rosdakarya

Ronny Hanitijo Soemitro. 2010, Metodologi Penelitian Hukum, Jakarta: Ghalia Indonesia

Peraturan Perundang Undangan :

Undang-Undang Dasar Negara Republik Indonesia Tahun 1945 (UUD NRI Tahun 1945).

Kitab Undang-Undang Hukum Perdata

Kitab Undang-Undang Hukum Acara Perdata

Undang-undang Nomor 5 Tahun 1960 Tentang Pokok-Pokok Agraria.

Undang-Undang Nomor 49/PRP Tahun 1960 Tentang Panitia Urusan Piutang Negara

Undang-Undang Nomor 4 Tahun 1996 Tentang Hak Tanggungan Atas Tanah Beserta Benda-Benda Yang Berkaitan Dengan Tanah

Undang-Undang Nomor 4 Tahun 1996 Tentang Hak Tanggungan

Undang-Undang Nomor 10 Tahun 1998 Tentang Perbankan

Undang-Undang Nomor 42 Tentang Jaminan Fidusia 
Undang-Undang Nomor 37 Tahun 2004 Tentang Kepailitan dan Penundaan Kewajiban Membayar Utang

Peraturan Menteri Keuangan Nomor 106/PMK.06/2013 Tentang Petunjuk Pelaksanaan Lelang

Peraturan Menteri Keuangan Nomor 102 /PMK.01/2008 Tentang Organisasi Dan Tata Kerja Instansi Vertikal Direktorat Jendral Kekayaan Negara 